\title{
かまぼこ製造工程におけるホルムアルデヒドの消長
}

\author{
城戸浩三*1 作間忠道*1 渡辺忠雄 ${ }^{* 2}$
}

(昭和 55 年 5 月 2 日受理)

\section{Changes in the Amount of Formaldehyde in Fish-paste During the Manufacture of Kamaboko}

\author{
Kōzō KIdo, Tadamichi Sakuma and Tadao Watanabe \\ $\left({ }^{* 1}\right.$ The Kitakyushu Municipal Institute of Environmental Health Sciences: \\ 2-1, Shinike 1-chome, Tobata-ku, Kitakyushu; \\ *2Department of Food Sciences \& Technology, Faculty of Agriculture, \\ Kyushu University: Hakozaki, Higashi-ku, Fukuoka)
}

The changes in the amount of formaldehyde in fish-paste during the manufacture of kamaboko, and the influence of kamaboko-board on the formaldehyde concentration in the edible part were studied.

The average values of formaldehyde concentration in old and new kamaboko-board were $4.6 \mathrm{ppm}$ and $9.4 \mathrm{ppm}$, respectively. In the materials of kamaboko, the formaldehyde concentration in lizard fish was $222 \mathrm{ppm}$ and that in mixtures of three species of fishes was $41 \mathrm{ppm}$. However, the value was greatly decreased after bleaching with water. A comparison of formaldehyde concentrations of raw and steamed fish-paste and the board suggested that the higher formaldehyde concentration observed in the lower part of kamaboko was a result of the vaporization of fomaldehyde from the upper part, not the transfer of formaldehyde from the board to the lower part.

(Received May 2, 1980)

食品中にホルムアルデヒドを添加することは食品衛生法 で禁止されている. しかしプラスチックの容器包装など からホルムアルデヒドの溶出, 移行がしばしば問題にな っているし，自然由来として規制をはずされだが，シ イタケなどのように食品自身ホルムアルデヒドを含んで いるものも見いだされている22.

著者らはさきに繊維および魚肉䘞製品中のホルムア ルデヒドを 2,4 - ジニトロフェニルヒドラゾンとしてガ スクロマトグラフにより定量する方法について検討し， いずれも良好な結果を得だ3).4.

本報ではこの分析法を用いて，かまぼこ製造工場で原 料魚から各製造工程におけるホルムアルデヒドの含有量 変化およびかまぼこ板から可食部へのホルムアルデヒド の移行の有無などその消長について検討したので報告す る.

\footnotetext{
*1 北九州市環境衛生研究所：北九州市戸畑区 新池 1 2-1

*2 九州大学農学部食糧化学工学科：福岡市東区箱崎
}

\section{実 験方法}

\section{1. 試 料}

分析に供したかまぼこはA社製品以外はすべて1979年 に市販品を購入した. Table 2 のかまぼこD のみが焙 焼したもので，他はすべて蒸したものである．同一検体 を 2 本ずつ購入して用いた。 その製造地は北九州市と山 口県である．板付かまぼこの場合はかまぼこを板の付着 面に平行に切ってそれぞれ約 $7 \mathrm{~mm}$ の厚さに 3 等分し, 板に近い部分から下，中，および上層とした。かほぼこ 板で Table 1 に用いた古板は，未使用のまま 1 年近く 放置されていたもので，新板は使用中のものである．か まぼこの板の材料はすべて杉であった.

\section{2. かまぼこの製造工程}

かまぼこの各製造工程における試料の採取は北九州市 のA社に依頼して次の要領で行った。

(1)原料魚一イシモチ, マェソ, メゴチ. (2)各魚体から 頭, 内臓を除き, 洗浄後肉を混合してペースト状にす る. (3)肉の 5 倍量の水 (水温約 $10^{\circ}$ ) で $3 \sim 5$ 回水さら 
しを行い, 沈殿した肉をスクリュープレスで脱水する. (4)スケトゥ（水さらし，脱水後冷凍すり身にしたもの. 日本水産 (株) 製) を高周波解凍 (11.8 ×ガヘルツ, 30 分間) し, (3)に加えてすりつぶす. (5)調味料（食塩, グ ルタミン酸ナトリウム，みりんなど）を加える. (6)成形 し, 板にのせる. (7)約 $90^{\circ}$ で 30 分間蒸して, 放冷する.

\section{3. 試 薬}

ホルマリンおよび塩酸は市販特級品を用いた。エチル アルコールは残留農薬用を用い, 酸化メチレンおよびへ キサンは市販一級品を蒸留して用いた。内部標準物質の $P, P^{\prime}$-DDT は農薬標準品 (純度 $99 \%$ 以上) を塩化メチ レンに溶解して用いた。 2,4 -ジニトロフェニルヒドラジ ン (2, 4-DNP) は市販特級品 $5 \mathrm{~g}$ を塩化メチレン $500 \mathrm{ml}$ で 2 回, 次いでへキサン $500 \mathrm{ml}$ で 2 回振とうして 精製し，減圧乾燥した，2,4-DNP 溶液は精製した 2,4DNP $1 \mathrm{~g}$ を $2 N$ 塩酸 $250 \mathrm{ml}$ に溶解し, ガラスフィル ター $(\mathrm{G} \cdot 2)$ でろ過して調製した。

4. 装 置

1）ガスクロマトグラフィー：(株) 島津製作所製 GC$5 \mathrm{~A}$ 型を用いて次の条件で行った.

検出後, FID; カラム管, ガラス製 (内径 $3 \mathrm{~mm}$, 長 さ $1 \mathrm{~m})$; 充てん剂, 担体一ユニポート HPS $(80 \sim 100$ メ ッシュ), 固定相液体一 $4 \% \mathrm{OV}-17$; 注入口温度一 $210^{\circ}$, カラム温度一 $190^{\circ}$; キャリアーガス, $\mathrm{N}_{2} 40 \mathrm{ml} / \mathrm{min}$.

2) クデルナ・ダニッシュ濃縮管 (KD 濃縮管): 500 $\mathrm{ml}$ のアダプターをつけ, $5 \mathrm{ml}$ 目盛付濃縮管を用いた。

\section{5. 実験 操 作}

\section{1 ホルマリンの標定}

市販の特級ホルマリン (約 $37 \%$ のホルムアルデヒド を含む) 約 $1 \mathrm{~g}$ をあらかじめ水を入れた科量びん中に精 密に量り, 水で $100 \mathrm{ml}$ に希釈した後, ヨウ素法5)によ り標定した。

\section{2 ホルムアルデヒド-2, 4-ジニトロフェニルヒド ラソンの調製}

前報 ${ }^{3)}$ に従って調製した。

\section{3 試験溶液の調製}

かまぼこは細切りにし，その $50 \mathrm{~g}$ に水 $50 \mathrm{ml}$ を加 え，ワーリングブレンダーで 2 分間かくはんした. その らち $50 \mathrm{~g}$ を $1 \mathrm{~L}$ 蒸留フラスコに入れ, 水 $200 \mathrm{ml}$ を加 えて水蒸気蒸留を行い, 留液 $1 \mathrm{~L}$ を集めて試験溶液とし た. 板については未使用の板はそのまま，かまぼこの付 いている板はかまぼこを庖丁で完全に除いた後，それぞ れかんなで薄く切り, その $5 \mathrm{~g}$ に水 $200 \mathrm{ml}$ を加えて水 蒸気蒸留を行い, 留液 $1 \mathrm{~L}$ を集めて試験溶液とした。 た対照としては水 $200 \mathrm{ml}$ を蒸留フラスコに入れ，同様 に $1 \mathrm{~L}$ の留液を集め試験溶液とした.

\section{4 定贯法}

前報3を応用して次の方法で定量を行った。

試験溶液 $500 \mathrm{ml}$ に塩酸 $30 \mathrm{ml}$ と 2, 4-DNP 溶液 20 $\mathrm{ml}$ を加え，これに塩化メチレン $100 \mathrm{ml}$ を加え 5 分間 振とうした後, 塩化メチレン層を分離する.ささらに塩化 メチレン $100 \mathrm{ml}$ で抽出し, ここに得た前後の塩化メチ レン層を合わせ, 無水硫酸ナトリウムで脱水した後, $\mathrm{KD}$ 濃縮器で $4.5 \mathrm{ml}$ 以下に濃縮し, $\mathrm{P}, \mathrm{P}^{\prime}$-DDT $40 \mathrm{ppm}$ を含む内部標準物質の塩化メチレン溶液 $0.5 \mathrm{ml}$ を加 え, 塩化メチレンで正確に $5 \mathrm{ml}$ にする. その $2 \mu 1$ を 実験方法 4.1) の条件で GC に注入する.

\section{結果および考察}

\section{1. 未使用かまほこ板中のホルムアルデヒド漊度}

かまぼこの古板と新板についてホルムアルデヒド濃度 を検討した．その結果を Table 1 に示す．古板はよく 乾燥されており， 3 枚の濃度範囲は 4.3〜 $4.8 \mathrm{ppm}$ であ った．新板は製材業者が材木からかまぼこ板に裁断して 乾燥した後, かまぼこ業者が仕入れたものである. 6 枚 の濃度範囲は 8.0 11.2 ppm で, 古板よりホルムアル デヒド濃度は高い. 板のホルムアルデヒド由来が板自体 からのものかあるいは貯木中に防腐の目的で使用されて いるのか明らかでない。

\section{2. かまぼこおよびかまぼこ板のホルムアルデヒド濃 度}

板付のかまぼこでは板の香りが可食部に移行すること が知られている.また前述のよらに未使用板にはA社使 用の板で平均值 $9.4 \mathrm{ppm}$ のホルムアルデヒドが含まれ ているので, 板から可食部へホルムアルデヒドが移行す ることも考えられる. 市販品 3 社の板付かまぼこ 4 種類 について, 下層, 中層および上層に分けた可食部と板の ホルムアルデヒド含有量を調査した. その結果を Table 2 に示す. 板はすべて A 社使用板と同じ杉材であるが, $\mathrm{A}$ 社使用板のホルムアルデヒド濃度より高いものが多 い.これは前述の結果から推測すると板の乾燥度の相違 によるものと考えられる.かまぽこAでは板のホルムア ルデヒド濃度は $22.6 \mathrm{ppm}$ である. また可食部は下層

Table 1. Analytical Data of Formaldehyde in Kamaboko-board

\begin{tabular}{r|cc}
$\begin{array}{c}\text { Kamaboko- } \\
\text { board }^{\mathrm{a}} \text { ) }\end{array}$ & $\begin{array}{c}\text { Formaldehyde } \\
\text { found } \\
\text { (ppm) }\end{array}$ & $\begin{array}{c}\mathrm{X} \pm \text { S.D. } \\
(\mathrm{ppm})\end{array}$ \\
\hline Old Board 1 & 4.3 & \\
2 & 4.7 & $4.6 \pm 0.2$ \\
3 & 4.8 & \\
New Board 1 & 8.0 & \\
2 & 8.1 & \\
3 & 8.7 & $9.4 \pm 1.2$ \\
4 & 9.9 & \\
5 & 10.7 & \\
6 & 11.2
\end{tabular}

a) The timbers were cryptmeria. 
Table 2. Analytical Data of Formaldehyde in Kamaboko and Kamaboko-board

\begin{tabular}{c|rrr|r}
\multirow{2}{*}{ Kamaboko } & \multicolumn{3}{|c}{ Formaldehyde found (ppm) } \\
\cline { 2 - 4 } & \multicolumn{3}{|c|}{ Part $^{\mathrm{a}}$} & \multirow{2}{*}{ Board $^{\mathrm{b})}$} \\
\cline { 2 - 4 } & Upper & Middle & Lower & \\
\hline A & 10.0 & 10.2 & 12.8 & 22.6 \\
B & 2.3 & 2.0 & 2.1 & 7.1 \\
C & 3.4 & 4.0 & 4.4 & 15.1 \\
D & 2.9 & 4.3 & 4.5 & 21.8
\end{tabular}

a) Each Kamaboko was sliced horizontally to the board and divided into three equal parts by length. One part was about $7 \mathrm{~mm}$ in thickness.

b) The timbers were cryptmeria.

$12.8 \mathrm{ppm}$ ，上層 $10.0 \mathrm{ppm}$ で下層の方がわずかに高い. かまぼこ Dでは板で $21.8 \mathrm{ppm}$ である. また可食部では 下層 $4.5 \mathrm{ppm}$ ，上層 $2.9 \mathrm{ppm}$ である.これら 4 検体の 結果から次のことが推測できる. (1)板のホルムアルデヒ ド濃度が高いことと, かまぼこ中のホルムアルデヒド濃 度が高いこととの関連性は低く，かまぼこに使用される 原料によってかまぼこのホルムアルデヒド濃度が決まる と考えられる。(2)かまぼこBを除いて下層の方が上層よ りもわずかにホルムアルデヒド濃度が高いので, 蒸すこ とによって板から可食部下層へのホルムアルデヒド移行 があるのかあるいは上層からのホルムアルデヒドの揮散 が考えられ，これを確かめるため次に，製造工場内での ホルムアルデヒドの消長を検討した.

\section{3. 原料魚からかまぼこ各製造工程でのホルムアルデ \\ ヒド含有量变化}

A社で製造されるかまぼこでの追跡調査を行った結果 を Table 3 に示す. 原料魚であるマエソのホルムアル デヒド濃度は $222 \mathrm{ppm}$ で非常に高い. 次の工程で原料 魚イシモチ，メゴチおよびマエソが混合され，その混合 すり身は $41 \mathrm{ppm}$ である. しかしその高いホルムアルデ ヒド含有量も水さらしにすることにより急激に減少す る. 工程 4. で加えられるスケトウのホルムアルデヒド 濃度は $1 \mathrm{ppm}$ である. 藤巻ら゙)はタラ, スケトウのホル ムアルデヒド含有量をトリクロロ䣫酸で除タンパク後フ セチルアセトン法で測定し，タラで 146〜204 ppm，ス ケトウで 90〜 $123 \mathrm{ppm}$ の值を得ている. 本報と藤巻ら のスケトウ中のホルムアルデヒド濃度の違いは, 本報の スケトウはすでに水さらし，脱水後冷凍してかまぼこ製 造工場に運び込まれたものであるので，この水さらしの 工程でホルムアルデヒドが十分に除去されたものと考え られる．また石綿ら》は過酸化水素処理によってかまぼ こ中のグリシンがホルムアルデヒドに変わることを報告 しているが，このかまぼこでは過酸化水素は水さらし中 には加えられていない. 工程 5. で食塩, グルタミン酸
Table 3. Change of Formaldehyde Concentration in Fish-paste on the Manufacturing Process

\begin{tabular}{|c|c|c|}
\hline \multicolumn{2}{|r|}{ Process } & $\begin{array}{c}\text { Formaldehyde } \\
\text { found }\end{array}$ \\
\hline & Materials & \\
\hline & Dram fish (Ishimochi) & 9.4 \\
\hline & Flat head (Megochi) & 4.6 \\
\hline & Lizard fish (Maeso) & 222 \\
\hline 2. & Mixture of 1 & 41 \\
\hline 3. & $\begin{array}{l}\text { Fish-paste dehydrate after } \\
\text { bleaching with water }\end{array}$ & 0.12 \\
\hline 4. & $\begin{array}{l}\text { Alaska pollack (Suketō) } \\
\text { (Bleached with water and } \\
\text { added to process } 3 . \text { ) }\end{array}$ & 1.0 \\
\hline 5. & $\begin{array}{l}\text { Fish-paste tasted with salt, } \\
\text { sodium glutamate and mirin }\end{array}$ & 3.5 \\
\hline \multirow[t]{5}{*}{6.} & Fish-paste with board (Raw) & \\
\hline & Upper & 3.4 \\
\hline & Middle & 3.9 \\
\hline & Lower & 3.9 \\
\hline & Board & 6.6 \\
\hline \multirow[t]{5}{*}{7.} & $\begin{array}{l}\text { Fish-paste product with } \\
\text { board (Steamed) }\end{array}$ & \\
\hline & Upper & 2.5 \\
\hline & Middle & 2.5 \\
\hline & Lower & 3.7 \\
\hline & Board & 7.6 \\
\hline
\end{tabular}

ナトリウムやみりんを加えることで少し濃度が高くなっ ているがこの原因は明らかではない，工程 6.では生の ねり魚肉をかまぼこ板にのせたものを，上,中，下各層に 分けてホルムアルデヒド濃度を検討した. その結果上層 だけわずかに低くなっている. 最終の工程 7. では, 工 程 6. の試料を蒸したものである. 工程 6 . の結果と比べ ると, 上, 中層でホルムアルデヒド濃度が低くなってい る.しかし下層ではあまり変化がない.この結果より, 上層より下層でホルムアルデヒド濃度が高いのは, 板か ら可食部へホルムアルデヒドが移行するのではなく, 蒸 すことによって上層のホルムアルデヒドが揮散すること によるものと考えられる.

\section{要 約}

かまぼこ製造工場において原料魚から各製造工程での ねり魚肉中のホルムアルデヒド含有量変化を調査し，ま たかまぼこ板から可食部へのホルムアルデヒドの移行の 有無について検討し, 次の結果を得た.

1. 未使用かまぼこ板で長く放置されていてよく乾燥 した古板と現在, 使用中の新板のホルムアルデヒド濃度 は古板 $(n=3)$ で $4.3 \sim 4.8 \mathrm{ppm}$, 新板 $(n=6)$ で 8.0〜 $11.2 \mathrm{ppm}$ であった。 
2. 市販品板付かまぼこ 4 種類について，かまぼこを 板の付着面に平行に切って上，中，下層に分けた試料お よび板のホルムアルデヒド含有量を調査した. その結果, 板の濃度が高ければかまぼこの濃度が高くなるといら関 連性は低く，かまぼこのホルムアルデヒド濃度が高いの はかまぼこの原料によるものと推定された。

3. 原料魚からかまぼこ各製造工程でのねり魚肉中の ホルムアルデヒド含有量を追跡調查した．原料魚である マェソは $222 \mathrm{ppm}$ で非常に濃度が高く, 他のイシモチ, メゴチはそれぞれ $9.4 \mathrm{ppm}, 4.6 \mathrm{ppm}$ であった. 3 つ の混合すり身は $41 \mathrm{ppm}$ であり，これを水さらし，脱水 するとホルムアルデヒド濃度は急激に減少した。 また上 層と下層で濃度差ができることの原因を調査するため, 生の板付かまぼこと蒸した板付かまぼこの上，中，下層 のホルムアルデヒド濃度を比較した. その結果, 下層の 濃度はほぼ同じで, 蒸しかまぼこの上, 中層の濃度が減 少していた。 このことより，板から可食部へのホルムア
ルデヒドの移行はほとんどなく，上層のホルムアルデヒ ドの揮散によって濃度ができると推定した。

謝 辞

本研究に当たり, 御助言御援助をいただいた北九州市 環境衛生研究所長園田真人博士をはじめ職員各位に深謝 いたします。

文献

1) 厚生省令 331 号 (1970).

2) 岡田敏史, 伊賀宗一郎, 伊阪 博: 衛生化学, 18, 353 357 (1972).

3) 城戸浩三，作間忠道：同上， 25，39４3 (1979).

4) 城戸浩三, 作間忠道, 渡辺忠雄: 同上, 26, 224 228 (1980).

5) 厚生省第34号 (1974).

6) 藤巻昌子, 武見和子, 天野立爾, 川田公平, 川城 璇: 食衛誌. 6, 510 512 (1965).

7) 石綿 肇, 谷村顕雄: 同上, 14, 249 252 (1973). 